\title{
PENGARUH KEPERCAYAAN DAN KEPUASAN TERHADAP MEREK PADA NIAT MEMBELI ULANG
}

\author{
Five Sulistyani Rosannah \\ PT Prima Putra Laksana Cilacap \\ e-mail: five_msi@yahoo.co.id
}

\begin{abstract}
The purpose of this study is to demonstrate the effect of trust and satisfaction of brand to the consumer evaluation on retailer and repurchase intentions. In this study, Zboja and Voorhees model (2006) was used as a confirmation model. The model was developed and tested using Structural Equation Modeling, especially in assessing direct and mediated effect. The proposed model includes five dimensions (brand trust, brand satisfaction, retailer trust, retailer satisfaction, and repurchase intentions). The shampoo user's was the respondent for this research. AMOS 16.0 was used to analyze the model. Eight hypotheses were developed. All hypotheses were supported. It means that the Zboja and Vorhees (2006) model can be generalize in convenience product. Base on the research findings, the researcher suggest that marketing managers must realize that perceptions of brands are transferred to the retailer that carry these products, so the retailer must satisfy them and earn their trust and repurchase intentions.
\end{abstract}

Keywords: brand trust, retailer trust, brand satisfaction, retailer satisfaction and repurchase intentions

\begin{abstract}
Abstrak
Tujuan penelitian ini adalah untuk mendemonstrasikan pengaruh kepercayaan dan kepuasan merek pada evaluasi konsumen pada ritel dan niat membeli ulang. Pada penelitian ini, model Zboja dan Voorhees (2006) digunakan sebagai model konfirmasi. Model tersebut dikembangkan dan diuji menggunakan Structural Equation Modeling (SEM), khususnya ketika menguji pengaruh langsung dan mediasi. Model yang diajukan dalam penelitian ini meliputi lima dimensi (kepercayaan merek, kepuasan merek, kepercayaan ritel, kepuasan ritel, dan niat membeli uang). Konsumen produk sampo menjadi responden untuk penelitian ini. Perangkat lunak AMOS 6.0 digunakan untuk menganalisis model penelitian. Terdapat delapan hipotesis yang bisa dikembangkan dalam penelitian ini dan seluruh hipotesis terdukung sehingga model Zboja dan Vorhees (2006) dapat digeneralisasi pada produk-produk convenience. Berdasarkan temuan yang muncul, peneliti berpandangan bahwa para manajer pemasaran harus menyadari persepsi merek yang ditransfer pada pihak ritel yang mengangkut produk-produk tersebut. Hal tersebut agar pihak ritel mampu memuaskan konsumen dan memperoleh kepercayaan dan niat membeli ulang dari para konsumennya.
\end{abstract}

Kata kunci: kepercayaan merek, kepercayaan ritel, kepuasan merek, kepuasan ritel, dan niat membeli ulang

\section{PENDAHULUAN}

Berdasarkan relationship marketing theory (Morgan dan Hunt, 1994; Geyskens, Steenkamp, dan Kumar, 1999), kepercayaan merupakan hal yang integral dengan kesuksesan suatu hubungan bisnis (Berry, 1995). Oleh karena itu, banyak peneliti pemasaran mempertimbangkan kepercayaan sebagai ante- seden perilaku hubungan yang positif, seperti komitmen sebuah organisasi untuk tetap menjalin hubungan bisnis (Gabriano dan Johnson, 1999; Geyskens et al., 1999). Salah satu indikator yang cukup handal untuk kelangsungan hidup dan keuntungan dari suatu proses bisnis adalah kelanjutan dari kepuasan pelanggan. Diperkirakan untuk menarik satu 
pelanggan baru diperlukan biaya mulai dari lima sampai lima belas kali, dibandingkan dengan menjaga hubungan dengan satu pelanggan lama (Zeithaml et al., 2009).

Beberapa peneliti telah mengeluh bahwa pentingnya merek telah menurun dalam lingkungan toko pengecer dan menjadi meningkat didominasi oleh superstore yang sangat kuat (Farris dan Ailawadi, 1992). Praktisi perlu memahami perkembangan merek pabrik karena dapat mempengaruhi evaluasi konsumen terhadap pengecer untuk tujuan peningkatan kesuksesan dalam lingkungan pengecer yang kompetitif (Zboja dan Voorhees, 2006). Pengukuran evaluasi konsumen dalam penelitian ini adalah kepercayaan dan kepuasan konsumen dan niat membeli ulang. Penelitian konseptual (Berry, 2000) dan penelitian empiris (Krishnan dan Hartline, 2001) menekankan pentingnya penelitian peran merek untuk perusahaan jasa. Meskipun demikian, kebanyakan penelitian bersifat konseptual dan fokus pada penetapan kebutuhan untuk pemahaman hubungan saling mempengaruhi antara merek dengan perusahaan jasa (Zboja dan Voorhees, 2006). Meskipun banyak konseptualisasi terdahulu masih terdapat sedikit peneliti yang mempertimbangkan dampak merek yang dijual oleh pengecer dapat mempengaruhi evaluasi konsumen pada perusahaan.

Usaha untuk memberikan wawasan baru pada dampak merek perusahaan pada persepsi konsumen atas pengecer, penelitian Zboja dan Voorhees (2006) menguji peran kepercayaan konsumen dan kepuasan terhadap merek dan hubungannya dengan kepercayaan terhadap pengecer dan kepuasan, dan akhirnya pada niat untuk membeli kembali. Penelitian tentang pemindahan sikap positif konsumen dari toko pengecer ke manufaktur (misalnya Beatty et al., 1996; Goff et al., 1997), belum terdapat pengujian empiris dari pengalihan potensial serupa dari manufaktur ke toko pengecer. Oleh karena itu, penelitian ini berusaha untuk melakukan pengujian empiris dari tiga hubungan kompleks antara merek, pengecer, dan konsumen seperti yang dilakukan oleh Zboja dan Voorhees (2006). Hal ini menunjukkan bahwa kepercayaan dan kepuasan terhadap merek berpengaruh pada niat membeli ulang melalui kepercayaan dan kepuasan pada pengecer.
Penelitian Zboja dan Voorhees (2006) menguji pengalaman dalam pembelian dua kategori produk yaitu komputer dan elektronik. Kedua kategori produk tersebut termasuk dalam kategori keterlibatan tinggi (specialty product). Penelitian yang dilakukan oleh peneliti merubah pilihan kategori produk menjadi barang convenience sesuai dengan saran future research dari Zboja dan Voorhees (2006). Selain itu, pemilihan kategori produk menjadi barang convenience dalam penelitian ini dilakukan untuk dapat mengetahui kekuatan generalisasi temuan penelitian Zboja dan Voorhees (2006). Konsumen yang ingin melakukan pembelian produk speciality product harus mempersiapkan dirinya, karena keputusan untuk pembelian produk speciality product merupakan perilaku dengan keterlibatan tinggi yang akan melibatkan faktor internal seperti motivasi, pembelajaran (sikap) dan faktor eksternal seperti norma subyektif yaitu keluarga, saudara dan teman. Sedangkan untuk pembelian produk convenience, konsumen tidak melalui proses keputusan yang panjang dan tidak banyak melibatkan orang lain dalam pengambilan keputusan. Selain itu, apabila dilihat dari biaya yang dikeluarkan untuk pembelian produk convenience relatif kecil, sehingga apabila konsumen salah dalam mengambil keputusan, maka dapat segera berpindah ke produk lain yang dianggap cocok.

Terjadinya niat membeli ulang dikemudian hari semua ini tidak lepas karena adanya kepuasan yang terbentuk karena kepuasan pada merek dan kepuasan pada pengecer. Niat membeli ulang dapat muncul karena adanya kepuasan pada pengecer dan karena terciptanya kepuasan pada merek yang terbentuk sebelumnya. Jika hasil evaluasi terhadap suatu merek, produk, atau jasa yang dipilih memenuhi atau melampaui ekspektasinya, maka pelanggan tersebut kemungkinan akan menunjukkan sikap positif, dan memiliki keinginan untuk membeli/menggunakan kembali merek, produk, atau jasa yang sama (repurchase intentions), dan keinginannya untuk bertindak sebagai referensi bagi orang lain (advocacy intentions).

Penelitian ini menarik untuk dilakukan karena beberapa alasan. Pertama, dalam mempertahankan konsumennya perusahaan harus mampu menciptakan kepuasan pelanggannya. Karena terciptanya kepuasan pelanggan dapat 
menguntungkan bagi perusahaan yaitu dapat terjadinya pembelian ulang. Adanya pembelian yang berulang ini sangat menguntungkan bagi perusahaan karena perusahaan dapat menghemat biaya promosi dan akan muncul konsumen baru karena adanya word of mouth dari konsumen ke konsumen. Kedua, karena penelitian sebelumnya tentang pengaruh kepercayaan dan kepuasan pada merek khususnya pada produk speciality product, sedangkan sekarang penelitian dilakukan tentang pengaruh kepercayaan dan kepuasan pada merek khususnya pada produk convenience.

\section{KAJIAN PUSTAKA}

Menurut Berry (1995), relationship marketing diartikan sebagai menarik, memelihara dan meningkatkan hubungan dengan pelanggan. Relationship marketing lebih merupakan pendekatan bersifat jangka panjang, dimana hal ini berbeda dengan pendekatan pemasaran transaksional yang lebih berorientasi jangka pendek. Tujuan dari pemasaran transaksional adalah untuk mendapatkan pelanggan semata, sedangkan tujuan dari relationship marketing adalah untuk mendapatkan dan mempertahankan pelanggan.

\section{Pengaruh kepuasan terhadap merek pada kepercayaan terhadap merek}

Ketika terdapat berbagai konseptualisasi kepercayaan dalam literatur pemasaran, salah satu yang populer ditawarkan oleh Morgan dan Hunt (1994) yaitu kepercayaan terjadi "ketika satu pihak telah percaya dengan reliabilitas dan integritas partner dalam suatu kegiatan perdagangan". Sama halnya dengan pendapat Moorman et al., (1993) yang mendefinisikan kepercayaan sebagai "keinginan untuk bergantung pada partner pertukaran yang telah terpercaya". Lou dan Lee (1999) membuat teori bahwa merek merupakan indikator bagi perusahaan manufaktur dalam menjalankan kontak dengan konsumen. Hal ini terjadi karena konsumen untuk produk tertentu membeli produk melalui perantara, sehingga tidak memiliki kontak personal dengan produsen. Oleh karena itu, perusahaan manufaktur mulai mengembangkan kepercayaan konsumen terhadap merek.

Lau dan Lee (1999) menambahkan, terciptanya kepuasan terhadap merek tertentu akan memberikan kepercayaan terhadap merek tersebut. Artinya, kepercayaan merek itu muncul ketika konsumen telah mendapatkan kepuasan melalui pengalaman menggunakan. Sehingga semakin tinggi kepuasan yang dirasakan konsumen maka akan memunculkan kepercayaan yang tinggi pula pada merek tersebut. Untuk penelitian ini, karena sifat kategori produk yang digunakan dalam survey adalah produk convenience yaitu shampo, kepercayaan pada produsen dan merek dapat saling menggantikan. Hal ini karena konsumen membeli shampoo tidak langsung ke produsen. Oleh karena itu dapat disusun hipotesis sebagai berikut:

H1: Kepuasan terhadap merek berpengaruh positif pada kepercayaan terhadap merek.

\section{Pengaruh kepuasan terhadap pengecer pada kepercayaan terhadap pengecer}

Oliver et al., (1997) mendefinisikan kepuasan sebagai "Penilaian dari produk atau jasa yang menyajikan tingkat kesenangan atas kemampuan pemenuhan konsumsi, termasuk kekurangan dan kelebihannya".

Dalam meta-analisis kepuasan dalam marketing, Geyskens et al., (1999) menemukan kepuasan merupakan anteseden dari kepercayaan. Hasil serupa ditemukan dalam setting pengecer (Bloemeer dan OderkerkenSchroe'der, 2002), dalam konteks kepercayaan merek (Delgado-Ballester dan MunueraAlema'n, 2001), seperti yang diusulkan dalam jasa oleh Singh dan Sirdeshmukh (2000. Kepercayaan akan terbangun dengan sendirinya ketika konsumen mendapatkan kepuasan. Pada akhirnya kepuasan yang terbentuk akan melahirkan kepercayaan pada pengecer sebagai wakil dari perusahaan manufaktur. Kepuasan yang selama ini terbangun lebih disebabkan pada pengalaman berhubungan dengan pengecer. Artinya semakin baik pelayanan yang diberikan oleh pengecer akan memberikan kepuasan pada konsumen. Hal ini pada akhirnya akan meningkatkan kepercayaan konsumen terhadap pengecer tersebut. Harapannya adalah bahwa hubungan kepuasankepercayaan ditemukan dalam penelitian selanjutnya baik pada merek dan pengecer di penelitian ini. Oleh karena itu, diusulkan hipotesis sebagai berikut:

H2: Kepuasan terhadap pengecer berpengaruh positif pada kepercayaan terhadap pengecer. 


\section{Pengaruh kepuasan terhadap merek pada kepuasan terhadap pengecer}

Pertanyaan utama yang akan diuji secara empiris selanjutnya dikemukakan yaitu apakah kepuasan pada merek dapat memiliki dampak positip pada kepuasan pada pengecer dan akhirnya niat untuk membeli kembali. Singh (1991) mendiskusikan kemungkinan bahwa konsumen bisa membuat penilaian kepuasan terpisah dari pengalaman berbelanjanya. Konsumen juga mengatakan bahwa bentuk hubungan tidak hanya dengan petugas penjualan (sales people) di toko pengecer, tetapi juga pada pengecer dan merek (Dodds et al., 1991). Penelitian telah menemukan bahwa perasaan positip terhadap sales people perusahaan "ditransfer" ke dalam perasaan yang sama terhadap pengecer dan/atau produsen (Beatty et al., 1996; Goff et al., 1997). Lebih spesifik lagi, Macintosh dan Lockshin (1997) mendemonstrasikan kesetiaan orang penjualan merupakan anteseden terhadap kesetiaan toko. Terciptanya kepuasan pada merek awalnya karena kenyataan yang diterima konsumen melebihi harapannya terhadap merek tersebut. Lau dan Lee (1999) menjelaskan lebih lanjut bahwa dengan terciptanya kepuasan pada merek akan memberikan kepuasan juga pada pengecer. Karena pengecer dalam hal ini berperan sebagai penyalur dari merek yang diterima oleh konsumen. Semakin baik perilaku pengecer dalam mendistribusikan merek maka akan mempengaruhi kepuasan konsumen. Sehingga diusulkan hipotesis sebagai berikut:

H3: Kepuasan terhadap merek berpengaruh positif pada kepuasan terhadap pengecer.

\section{Pengaruh kepercayaan terhadap merek pada kepercayaan terhadap pengecer}

Boulding (1956) mengkaitkan bahwa perilaku manusia lebih dikendalikan oleh persepsi image dibandingkan realita obyektif. Persepsi, sesungguhnya kadang merupakan realita dalam pikiran konsumen. Jika pengecer dapat menciptakan koneksi (dalam pikiran konsumen) dengan merek populer yang dibawa, pengecer dapat memperoleh manfaat dari powerfull brand. Berdasarkan penemuan ini, hipotesis berikut ini diusulkan bahwa kepercayaan pada merek dapat memiliki transfer yang serupa pada pengecer. Oleh karena itu, diusulkan hipotesis sebagai berikut:
H4: Kepercayaan terhadap merek berpengaruh positif pada kepercayaan terhadap pengecer.

\section{Pengaruh kepuasan terhadap pengecer pada niat membeli ulang}

Niat membeli ulang, sama dengan kesetiaan, keinginan untuk membayar price premium, word-of-mouth, dan tuntutan yang merepresentasikan lima niat keperilakukan yang digambarkan oleh Zeithaml et al., (1996). Kesetiaan dan aspek pembelian kembali dari taksonomi yang pada dasarnya bersifat serupa. Oliver et al., (1997) sebagai contoh tindakan operasional kesetiaan berupa pengulangan penggunaan. Delgado-Ballester dan MunueraAlema'n (2001) dan Macintosh dan Lockshin (1997) menggunakan niat membeli kembali sebagai elemen kesetiaan dalam konteks merek dan toko. Terdapat beberapa perdebatan dalam literatur berkaitan dengan dampak kepuasan pada niat membeli kembali dan kepuasan. Delgado-Ballester et al., (2003) menyarankan bahwa kepuasan mempengaruhi kesetiaan secara langsung. Oleh karena itu, diusulkan hipotesis sebagai berikut:

H5: kepuasan terhadap pengecer berpengaruh positif pada niat membeli ulang.

\section{Pengaruh kepercayaan terhadap pengecer pada niat membeli ulang}

Kepercayaan pada pengecer dalam beberapa literatur menjadi perdebatan tentang pengaruhnya pada niat membeli ulang. Banyak yang menemukan hubungan langsung (misalnya Bearden dan Teel, 1983; Cronin dan Taylor, 1992; Oliver et al., 1997; Selnes, 1998), sedangkan yang lain menyarankan bahwa kepercayaan adalah anteseden yang dominan dari niat membeli ulang (misalnya Doney dan Cannon, 1997). Perdebatan belum selesai karena Ranaweera dan Prabhu (2003) menemukan kepercayaan dan kepuasan memiliki dampak positif pada ingatan konsumen. Garbarino dan Johnson (1999) menemukan kepuasan menjadi kunci untuk ocasional consumer, sedangkan kepercayaan lebih penting untuk pelanggan yang konsisten. DelgadoBallester et al., (2003) menyarankan bahwa kepercayaan mempengaruhi kesetiaan secara langsung. Hipotesis berikut mengusulkan hubungan langsung dari kepercayaan pada 
pengecer dengan niat membeli ulang. Oleh karena itu, diusulkan hipotesis sebagai berikut:

H6: kepercayaan terhadap pengecer berpengaruh positif pada niat membeli ulang.

\section{Peran mediasi kepercayaan terhadap pengecer}

Pertanyaan selanjutnya dalam penelitian menempatkan sifat hubungan antara kepercayaan dan kepuasan dengan merek dan niat membeli ulang dengan pengecer. Pengecer mendapatkan sejumlah manfaat dari mendapatkan powerfull brand, termasuk peningkatan image untuk pengecer dengan konsumen, hubungan kepercayaan dan kredibilitas dengan konsumen, dan pre-established demand (Webster, 2000). Penemuan ini dan pendapat penelitian ini mengarah kepada mediasi yang diusulkan:

H7: Kepercayaan terhadap merek berpengaruh pada niat membeli ulang melalui kepercayaan pada pengecer sebagai variabel mediasi

\section{Peran mediasi kepuasan terhadap pengecer}

Kepuasan konsumen adalah penilaian evaluatif atas pilihan terakhir dari transaksi tertentu (Kotler, 2000). Kepuasan dapat dinilai secara langsung sebagai perasaan konsumen secara keseluruhan. Kepuasan konsumen juga dipengaruhi oleh dua faktor yaitu pengharapan dan kinerja jasa yang dialami. Kepuasan terjadi ketika kinerja yang dialami sama atau lebih besar dari pengharapan (Zeithaml, et al., 2009). Penemuan penelitian ini mengarah kepada mediasi yang diusulkan:
H8: Kepuasan terhadap merek berpengaruh pada niat membeli ulang melalui kepuasan pada pengecer sebagai variabel mediasi.

Perbedaan antara penelitian terdahulu dengan saat ini, yang dilakukan oleh Zboja dan Voorhees (2006), kategori produk yang digunakan termasuk dalam kategori high involvement, seperti komputer dan mesin foto kopi. Sedangkan Kuntjara (2007, kategori produk yang digunakan termasuk dalam kategori high involvement, seperti beton dan bahan kimia. Sedangkan pada Puspitasari (2006), kategori produk yang digunakan termasuk dalam kategori high involvement, yaitu jasa penerbangan pada maskapai Garuda.

Sedangkan penelitian sekarang yang dilakukan menggunakan produk convenience. Berdasarkan survei yang dilakukan pada produk shampo, diperoleh hasil bahwa produk shampo berada dalam kategori low involvement. Hasil ini dapat ditunjukan dari kecenderungan responden dalam menganggap produk shampo sebagai produk yang tidak terlalu penting, tidak harus dimiliki dan responden tidak mempunyai ketertarikan yang kuat terhadap produk tersebut. Alasan pengambilan produk low involvement dalam penelitian ini adalah untuk melihat perbedaannya dengan penelitian sebelumnya yang menggunakan produk high involvement.

\section{Model Penelitian}

Model yang diadaptasikan dalam penelitian ini terlihat dalam Gambar 1.

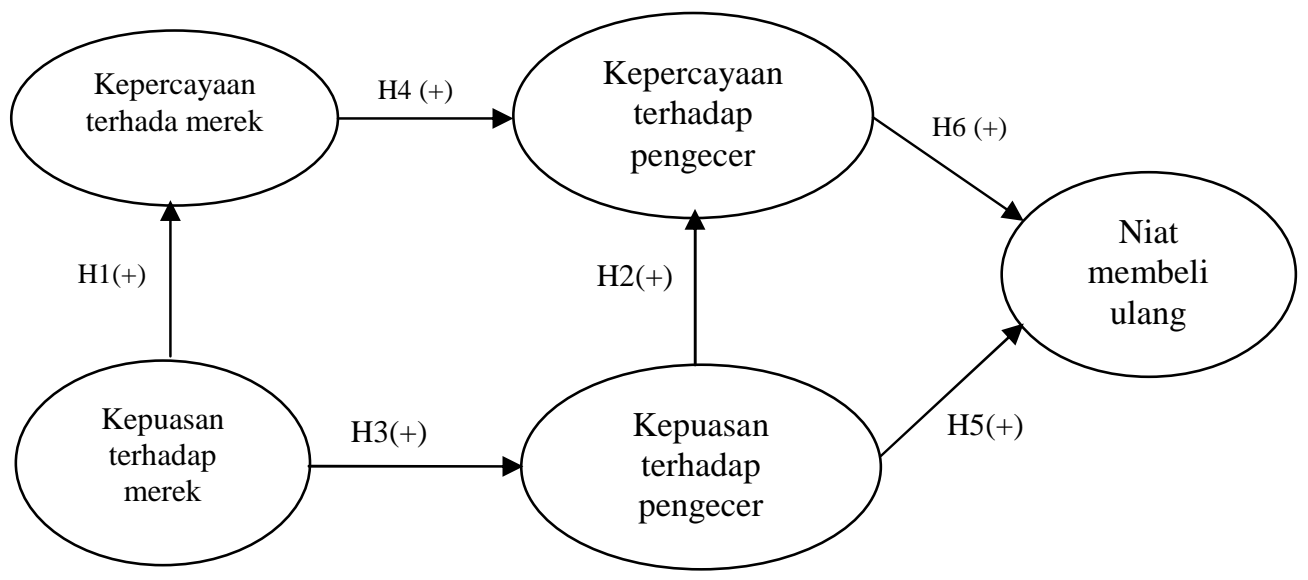

Gambar 1: Model Penelitian

Sumber: Zboja dan Voorhees (2006). 


\section{METODE PENELITIAN}

\section{Desain Penelitian}

Penelitian ini menggunakan pendekatan formal study. Menurut Cooper dan Schindler (2008: 140), formal study dimulai dengan suatu hipotesis atau pertanyaan penelitian yang kemudian melibatkan prosedur dan spesifikasi sumber data yang sesuai, yang bertujuan untuk menguji hipotesis atau jawaban atas pertanyaan penelitian yang diajukan. Penelitian ini menggunakan metode survei dengan level analisis individu (konsumen). Penelitian ini dilakukan dengan menggunakan instrumen pengumpulan data berupa kuesioner yang terdiri dari sejumlah pertanyaan terstruktur. Berdasarkan setting penelitian, penelitian ini termasuk dalam penelitian studi lapangan (field study) karena penelitian ini dilakukan pada kondisi lingkungan yang sebenarnya yaitu pada pengguna shampo di Kota Yogyakarta dan sekitarnya. Pengembangan instrumen penelitian dikembangkan dari indikator yang dikembangkan oleh Zboja dan Voorhees (2006) dan Lau dan Lee (1999) dengan menggunakan Skala Likert dari 1 (sangat tidak setuju) sampai 5 (sangat setuju). Jumlah indikator sebanyak 24 butir pertanyaan.

Populasi penelitian ini adalah para pengguna shampo di Yogyakarta. Penelitian dilakukan secara survey untuk mengumpulkan data penelitian. Responden diminta mengisi kuesioner bersifat self report berdasarkan pengalaman dalam pembelian produk convenience dalam hal ini shampo.

Pengambilan sampel didasarkan pada metode penentuan sampel non probability dengan teknik purposive sampling. Adapun sampel dalam penelitian ini adalah para pengguna shampo. Jenis teknik purposive sampling yang digunakan adalah judgment sampling, dengan cara peneliti memilih anggota-anggota sampel untuk memenuhi kriteria tertentu (Cooper dan Schindler, 2008:424). Adapun kriteria sampel yang diambil adalah para pengguna shampo yang telah menggunakan minimal kurang lebih dari 3 bulan dengan asumsi peng- guna shampo tersebut telah dapat merasakan dan mengevaluasi manfaat yang diperoleh dari shampo yang digunakan. Penelitian ini melibatkan 200 responden (Hair et al, 2006).

\section{HASIL ANALISIS}

Hasil uji validitas dan reliabilitas dengan menggunakan sampel besar menunjukkan bahwa item-item kuesioner telah memenuhi kriteria valid dan reliable. Tabel 2. menunjukkan nilai KMO dari semua variabel melebihi nilai cut off value 0,5 dan nilai Tes Bartlett signifikan, artinya data selanjutnya dapat dianalisis dengan Analisis Faktor.

Tabel 3 menunjukkan factor loading tiap item dalam kuesioner dapat dikatakan signifikan jika loading masing-masing item lebih besar dari 0,4 (Hair et al., 2006). Selanjutnya untuk memenuhi kriteria validitas, setiap item dalam konstruk harus memiliki loading tinggi pada konstruk dan cross loading harus lebih rendah dibanding dengan loading item dalam konstruk.

Reliabilitas merupakan pengujian konsistensi dan stabilitas suatu pengukur. Uji reliabilitas dilakukan dengan cara yang sama seperti yang dilakukan di pengujian pilot test sebelumnya, yaitu diukur dengan koefisien Cronbach Alpha dengan ambang minimal 0,6. Adapun hasil uji reliabilitasnya dapat dilihat di Tabel 4.

Berdasakan tabel 4 diketahui bahwa reliabilitas konstruk terpenuhi. Hal ini dapat dilihat dari nilai Cronbach Alpha menunjukkan nilai antara 0,824 sampai 0.911 . Dengan demikian, konstruk-konstruk tersebut telah memenuhi stabilitasi dan konsistensi yaitu bahwa antara satu item dengan item yang lain dalam satu konstruk saling berkorelasi tinggi ditunjukkan dengan nilai Cronbach's Alpha sebesar lebih besar dari 0,7. Dari ragam uji pengukuran yang telah dilakukan, baik dengan melakukan uji validitas maupun uji reliabilitas, maka data yang digunakan menunjukkan kualitas instrumen yang baik.

Tabel 2: Nilai KMO dan Tes Bartlett Field Test

\begin{tabular}{lcc}
\hline Variabel & Nilai KMO & Nilai Bartlett \\
\cline { 1 - 2 } $\begin{array}{l}\text { Kepercayaan terhadap merek, kepercayaan terhadap pengeer, } \\
\text { kepuasan terhadap merek, kepuasan terhadap pengecer, dan } \\
\text { niat beli ulang }\end{array}$ & 0,870 & 0,000 \\
\hline
\end{tabular}


Tabel 3: Factor Loading Tiap Item Kesioner

\begin{tabular}{|c|c|c|c|c|c|}
\hline $\begin{array}{l}\text { Kode } \\
\text { Item }\end{array}$ & 1 & 2 & 3 & 4 & 5 \\
\hline Q1 & 0,723 & & & & \\
\hline Q1 & 0,772 & & & & \\
\hline Q3 & 0,758 & & & & \\
\hline Q4 & 0,740 & & & & \\
\hline Q5 & 0,801 & & & & \\
\hline Q6 & 0,731 & & & & \\
\hline Q7 & & 0,866 & & & \\
\hline Q8 & & 0,799 & & & \\
\hline Q9 & & 0,817 & & & \\
\hline Q10 & & 0,816 & & & \\
\hline Q11 & & 0,849 & & & \\
\hline Q12 & & & 0,827 & & \\
\hline Q13 & & & 0,798 & & \\
\hline Q14 & & & 0,808 & & \\
\hline Q15 & & & 0,817 & & \\
\hline Q16 & & & 0,817 & & \\
\hline Q17 & & & & 0,830 & \\
\hline Q18 & & & & 0,806 & \\
\hline Q19 & & & & 0,825 & \\
\hline Q20 & & & & 0,810 & \\
\hline Q21 & & & & 0,822 & \\
\hline Q22 & & & & & 0,838 \\
\hline Q23 & & & & & 0,844 \\
\hline Q24 & & & & & 0,811 \\
\hline
\end{tabular}

Data primer yang diolah

Tabel 4: Hasil Reliablitas

\begin{tabular}{lcc}
\hline \multicolumn{1}{c}{ Variabel } & $\begin{array}{c}\text { Cronbach's } \\
\text { Alpha }\end{array}$ & Keterangan \\
\hline Kepercayaan terhadap merek & 0,871 & Reliabel \\
Kepercayaan terhadap pengecer & 0,906 & Reliabel \\
Kepuasan terhadap merek & 0,911 & Reliabel \\
Kepuasan terhadap pengecer & 0,900 & Reliabel \\
Niat beli ulang & 0,824 & Reliabel \\
\hline
\end{tabular}

Data primer yang diolah

\section{Hasil Uji Normalitas}

Uji normalitas dilakukan dengan membandingkan nilai critical ratio (CR) skewness dan kurtosis dengan nilai kritis pada tingkat signifikansi $1 \%$ yaitu sebesar kurang lebih 2,58 atau 5\% yaitu kurang lebih 1,96 (Hair et al., 2006) dengan alat analisis AMOS 16. Pada penelitian ini ditetapkan nilai critical ratio $(\mathrm{CR})$ skewness dan kurtosis dengan nilai kritis pada tingkat signifikansi $1 \%$ yaitu sebesar kurang lebih
2,58, sehingga data akan terdistribusi secara normal jika critical ratio skewnees dan kurtosis dibawah harga mutlak 2,58.

Berdasarkan output uji normalitas data seperti yang terlihat pada Tabel 5, secara univariate nilai critical ratio (cr) skewness dan nilai critical ratio (cr) kurtosis semua indikator dibawah harga mutlak 2,58. Artinya, secara univariate data tersebut terdistribusi dengan normal. 
Tabel 5: Hasil Uji Normalitas

\begin{tabular}{ccccccc}
\hline Variabel & min & max & skew & c.r. & kurtosis & c.r. \\
\hline Q21 & 2,000 & 5,000 & $-0,147$ & $-0,847$ & $-0,754$ & $-2,176$ \\
Q16 & 1,000 & 5,000 & $-0,137$ & $-0,793$ & $-0,661$ & $-1,908$ \\
Q11 & 2,000 & 5,000 & $-0,179$ & $-1,034$ & $-0,575$ & $-1,658$ \\
Q6 & 3,000 & 5,000 & 0,126 & 0,727 & $-0,682$ & $-1,970$ \\
Q22 & 1,000 & 5,000 & 0,086 & 0,499 & $-0,760$ & $-2,194$ \\
Q23 & 1,000 & 5,000 & $-0,138$ & $-0,797$ & $-0,569$ & $-2,284$ \\
Q24 & 1,000 & 5,000 & $-0,228$ & $-1,318$ & $-0,769$ & $-1,641$ \\
Q17 & 2,000 & 5,000 & $-0,099$ & $-0,570$ & $-0,679$ & $-2,220$ \\
Q18 & 2,000 & 5,000 & $-0,123$ & $-0,712$ & $-1,757$ & $-1,959$ \\
Q19 & 2,000 & 5,000 & $-0,193$ & $-1,116$ & $-0,757$ & $-2,186$ \\
Q20 & 2,000 & 5,000 & $-0,171$ & $-0,985$ & $-0,711$ & $-2,051$ \\
Q12 & 1,000 & 5,000 & $-0,148$ & $-0,855$ & $-0,630$ & $-1,817$ \\
Q13 & 1,000 & 5,000 & $-0,099$ & $-0,571$ & $-0,605$ & $-1,747$ \\
Q14 & 1,000 & 5,000 & $-0,121$ & $-0,696$ & $-0,648$ & $-1,870$ \\
Q15 & 1,000 & 5,000 & $-0,054$ & $-0,310$ & $-0,585$ & $-1,688$ \\
Q7 & 2,000 & 5,000 & $-0,064$ & $-0,368$ & $-0,777$ & $-2,244$ \\
Q8 & 2,000 & 5,000 & $-0,223$ & $-1,286$ & $-0,622$ & $-1,796$ \\
Q9 & 2,000 & 5,000 & $-0,097$ & $-0,559$ & $-0,702$ & $-2,027$ \\
Q10 & 2,000 & 5,000 & $-0,045$ & $-0,258$ & $-0,619$ & $-1,787$ \\
Q1 & 3,000 & 5,000 & 0,075 & 0,435 & $-0,571$ & $-1,648$ \\
Q2 & 3,000 & 5,000 & 0,006 & 0,033 & $-0,753$ & $-2,173$ \\
Q3 & 3,000 & 5,000 & 0,082 & 0,474 & $-0,626$ & $-1,807$ \\
Q4 & 3,000 & 5,000 & 0,106 & 0,611 & $-0,551$ & $-1,590$ \\
Q5 & 3,000 & 5,000 & 0,073 & 0,419 & $-0,739$ & $-2,133$ \\
Multivariate & & & & & 88,547 & 17,723 \\
\hline Din
\end{tabular}

Data primer yang diolah

\section{Hasil Uji Outliers}

Uji outliers dilakukan dengan menganalisis nilai mahalanobis $d$-square pada tingkat $\mathrm{p}<$ 0,005 . Mahalanobis distance digunakan untuk mengukur apakah data ada yang outlier yaitu mendeteksi apakah skor observasi ada yang jauh berbeda dengan skor centroidnya. Nilai mahalanobis $d$-square dievaluasi dengan menggunakan $\chi^{2}$ pada derajat bebas sebesar jumlah indikator variabel yang digunakan dalam penelitian (Hair et al., 2006). Alat analisis statistik yang digunakan adalah AMOS 16.0.
Pada penelitian ini, model mengunakan 24 indikator pengukur konstruk yang ada meliputi konstruk kepercayaan terhadap merek sebanyak 6 indikator, kepercayaan terhadap pengecer sebanyak 4 indikator, kepuasan terhadap merek sebanyak 6 indikator, kepuasan terhadap pengecer sebanyak 5 indikator, dan niat beli ulang sebanyak 3 indikator. Oleh karena itu, untuk semua observasi yang mempunyai nilai mahalanobis distance lebih besar dari $\chi^{2}(24,0,005)=45,55$ adalah multivariate outlier. Hasil pengujian outliers dengan melakukan pengecekan nilai mahalanobis $d$-square dapat dilihat pada Tabel 6 .

Tabel 6: Hasil Uji Outliers

\begin{tabular}{ccccl}
\hline Nomor Observasi & Mahalanobis d-squared & p1 & p2 & \multicolumn{1}{c}{ Cut off value } \\
\hline 166 & 55,874 & 0,000 & 0,047 & Nilai mahalanobis distance \\
146 & 55,438 & 0,000 & 0,001 & yang lebih besar dari $\chi^{2}(24$, \\
93 & 54,265 & 0,000 & 0,000 & $0,005)=45,55$ adalah \\
24 & 52,285 & 0,001 & 0,000 & multivariate outlier. \\
155 & 51,892 & 0,001 & 0,000 & \\
104 & 51,133 & 0,001 & 0,000 & \\
$\ldots$ & $\ldots$ & $\ldots$ & $\ldots$ & \\
76 & 47,880 & 0,003 & 0,000 & \\
\hline
\end{tabular}

Data primer yang diolah 
Tabel 6 menyajikan informasi sebagai berikut: terdapat 11 observasi yang terindikasi mempunyai outliers. Data-data tersebut berada pada observasi $80,128,99,76,172,104,155$, 24, 93, 146, dan 166. Data-data ini tetap dipertahankan karena merupakan elemen dari populasi yang ada, sehingga patut untuk dipertahankan untuk alasan generabilitas. Jika outliers ini dibuang, peneliti akan mendapatkan hasil analisis multivariat yang lebih baik tetapi tidak pada aspek generabilitas (Hair et al., 2006).

\section{Hasil Uji Validitas Model Pengukuran (Goodness of Fit Model)}

Penilaian validitas dalam model struktural antara lain ditunjukkan dengan structural model fit (kecocokan model struktural) yang baik. Berdasarkan output AMOS 16.0, nilai masing-masing indeks goodness-of-fit dapat dilihat pada Tabel 7.

Hasil pengujian goodness of fit model pada Tabel 7 menunjukkan bahwa terdapat beberapa nilai goodness of fit yang tidak memenuhi kriteria kecocokan model yaitu nilai AGFI (Adjusted Goodness of Fit). AGFI merupakan pengembangan dari goodness of fit yang disesuaikan dengan ratio $d f$ untuk propose model dengan $d f$ untuk null model. Nilai AGFI dalam penelitian ini dibawah cut off $\geq 0,90$ yaitu sebesar $\geq 0,880$.

Untuk nilai chi-square yang memenuhi kriteria diharapkan kecil, artinya hanya sedikit perbedaan yang terjadi antara model yang diajukan dalam penelitian dengan realitas yang sesungguhnya. Sebaliknya, $p$-value yang merupakan statistical significance of $\chi 2$, diharapkan besar (diharapkan $>0,05)$, bukan kecil $(<0,05)$, karena semakin kecil p-value semakin besar peluang tidak samanya sampel yang diobservasi dengan matriks kovarians yang diestimasi SEM. Padahal, nilai chi-square akan meningkat seiring dengan meningkatnya jumlah sampel dan penilaian $p$-value juga menjadi kurang bermakna jika ukuran sampel besar (Hair et al., 2006).

Nilai $d f$ menunjukkan lebih dari nol atau model penelitian ini overidentified, dengan demikian masih terbuka peluang modifikasi model jika ingin meningkatkan goodness of fit model yang diajukan, yaitu sebanyak 244 kali. Modifikasi model untuk mendapatkan goodness of fit yang lebih baik dapat dilakukan dengan cara menambahkan atau mengurangi jalur pada model disertai dukungan teori yang kuat. Secara umum, dapat disimpulkan bahwa model yang diajukan relatif dapat diterima karena model tersebut dapat menjelaskan data yang sesungguhnya mengenai pola hubungan antar konstruk penelitian. Hal ini ditunjukkan dengan terpenuhinya kriteria indeks-indeks goodness of fit yang mempunyai nilai yang relatif memenuhi persyaratan berdasarkan cut off value yang direkomendasikan Hair et al., (2006). Jika dibandingkan dengan model penelitian Zboja dan Voorhees (2006), model ini memberikan hasil goodness of fit yang hampir setara. Model Zboja dan Voorhees (2006) memberikan hasil goodness of fit dengan menghasilkan nili CFI sebesar 0,98, sedangkan model penelitian ini menghasilkan nilai CFI sebesar 0.987. Untuk nilai TLI, Zboja dan Voorhees (2006) menghasilkan nilai sebesar 0.97, sedangkan model penelitian ini menghasilkan nilai sebesar 0.985 .

Tabel 7: Hasil Goodness of Fit Model

\begin{tabular}{llrc}
\hline \multicolumn{1}{c}{ Goodness of fit index } & \multicolumn{1}{c}{ Cut off Value } & $\begin{array}{c}\text { Nilai Goodness of } \\
\text { fit index }\end{array}$ & Hasil \\
\hline$\chi^{2}$ (chi-square) & Semakin kecil semakin baik & 278,403 & Baik \\
p-value (statistical significance of $\chi 2)$ & $\geq 0,05$ & 0,064 & Baik \\
df (degrees offreedom) & $\mathrm{df} \geq 0$ & 244 & Baik \\
GFI & $\geq 0,90$ & 0,902 & Baik \\
AGFI & $\geq 0,90$ & 0,880 & Buruk \\
RMSEA & $\leq 0,08$ & 0,027 & Baik \\
NFI & $\geq 0,90$ & 0,906 & Baik \\
CFI & $\geq 0,95$ & 0,987 & Baik \\
TLI & $\geq 0,95$ & 0,985 & Baik \\
CMIN/DF & Antara 1 sampai 3 (range: 3 to 1) & 1,875 & Baik \\
\hline
\end{tabular}

Data primer yang diolah 


\section{Pengujian Hipotesis}

Pengaruh suatu konstruk pada konstruk yang lain diuji dengan menganalisis koefisien jalur pada taraf signifikansi tertentu. Koefisien jalur dikatakan signifikan bila C.R > 1,96 untuk tingkat signifikansi 0,05 atau C.R > 2,58 untuk tingkat signifikansi 0,01. Selanjutnya dianalisis kesesuaian arah hubungan koefisien dengan arah hubungan yang telah dihipotesiskan. Hipotesis penelitian dikatakan terdukung $\left(\mathrm{H}_{\mathrm{o}}\right.$ ditolak dan $\mathrm{H}_{\mathrm{a}}$ diterima) jika arah hubungan sesuai dengan yang dihipotesiskan serta ditunjang nilai C.R yang memenuhi syarat. Dalam penelitian ini digunakan tingkat signifikansi 0,01 atau 1\% yaitu C.R > 2,58. Tabel 12 dan gambar 2 memuat hasil pengujian hipotesis dalam penelitian ini.

Tabel 8: Hasil Pengujian Hipotesis

\begin{tabular}{|c|c|c|c|c|c|c|c|c|c|c|}
\hline \multicolumn{7}{|c|}{ Hipotesis } & \multirow{2}{*}{$\frac{\text { Arah }}{+}$} & \multirow{2}{*}{$\begin{array}{c}\text { Estimate } \\
0,260\end{array}$} & \multirow{2}{*}{$\frac{\text { C.R }}{6,364 * * *}$} & \multirow{2}{*}{$\begin{array}{c}\begin{array}{c}\text { Analisis } \\
\text { Hipotesis }\end{array} \\
\text { Terdukung }\end{array}$} \\
\hline H1 & : & TM & $\leftarrow$ & KM & & & & & & \\
\hline $\mathrm{H} 2$ & : & $\mathrm{TP}$ & $\leftarrow$ & $\mathrm{KP}$ & & & + & 0,348 & $4,850 * * *$ & Terdukung \\
\hline H3 & : & KP & $\leftarrow$ & KM & & & + & 0,215 & $3,334 * * *$ & Terdukung \\
\hline $\mathrm{H} 4$ & : & $\mathrm{TP}$ & $\leftarrow$ & $\mathrm{TM}$ & & & + & 0,318 & 2,541 & Terdukung \\
\hline H5 & : & BU & $\leftarrow$ & $\mathrm{KP}$ & & & + & 0,339 & $3,610^{* * * *}$ & Terdukung \\
\hline H6 & : & BU & $\leftarrow$ & TP & & & + & 0,258 & $2,646 * * *$ & Terdukung \\
\hline $\mathrm{H} 7$ & : & $\mathrm{BU}$ & $\leftarrow$ & TP & $\leftarrow$ & $\mathrm{TM}$ & + & & & Terdukung \\
\hline H8 & : & $\mathrm{BU}$ & $\leftarrow$ & $\mathrm{KP}$ & $\leftarrow$ & KM & + & & & Terdukung \\
\hline
\end{tabular}

Keterangan $* * *$ : Signifikan pada $\mathrm{p}=0,01$

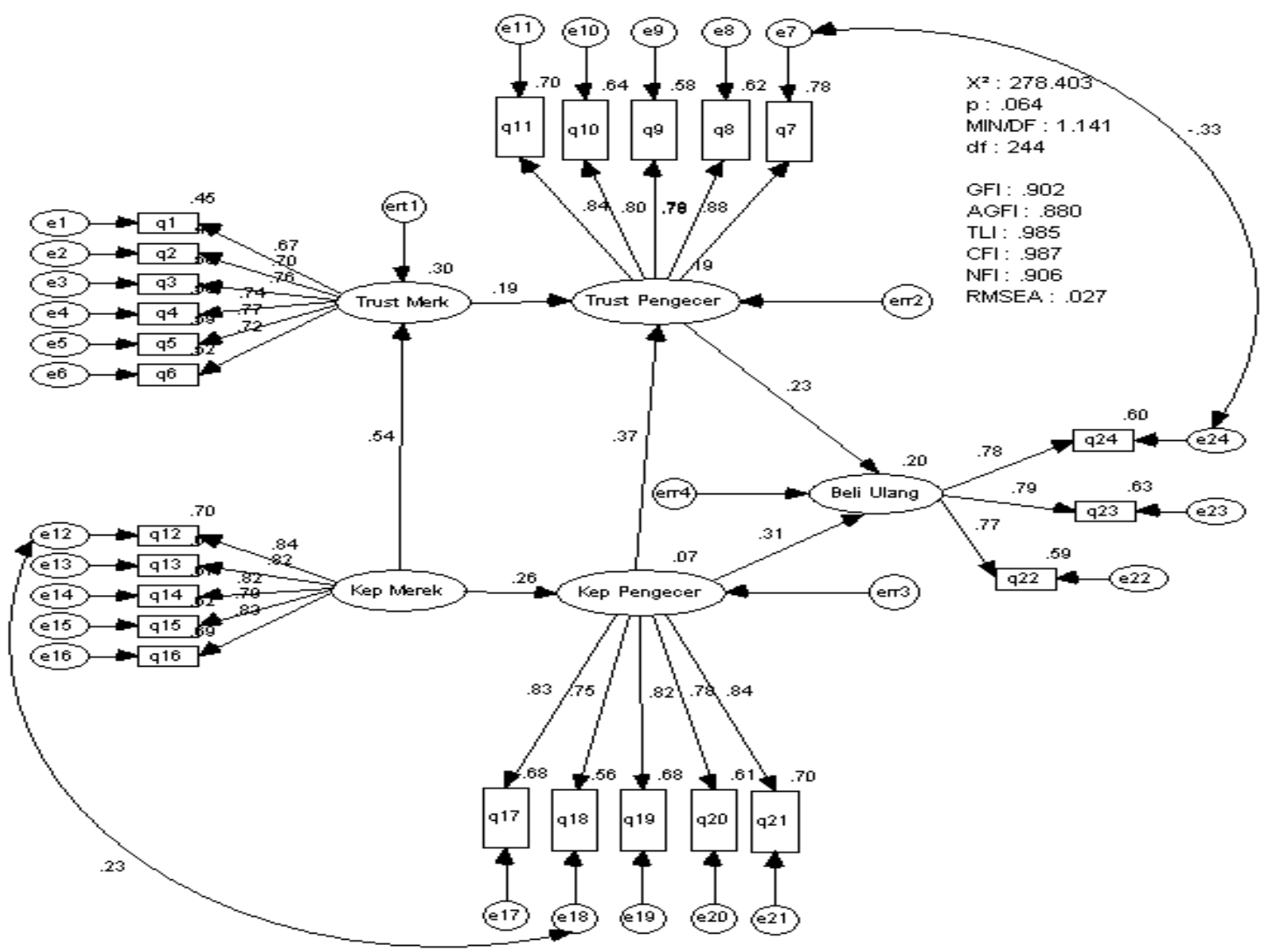

Gambar 2: Model Penelitian 


\section{PEMBAHASAN}

\section{Hubungan kepuasan terhadap merek pada kepercayaan terhadap merek}

Berdasarkan hasil pengujian hipotesis pertama menunjukkan kepuasan terhadap merek berpengaruh positif pada kepercayaan terhadap merek. Temuan ini konsisten dengan penelitian Zboja dan Voorhees (2006) untuk konteks speciality product berupa barang elektronik. Kepuasan terhadap merek dapat didefinisikan sebagai hasil evaluasi subjektif bahwa alternatif merek yang dipilih memenuhi atau melampaui ekspektasi konsumen (Bloemer dan Kasper, 1995, dalam Lau dan Lee, 1999). Sedangkan Morgan dan Hunt (1994) menyatakan bahwa kepercayaan terjadi ketika satu pihak telah percaya dengan reliabilitas dan integritas partner dalam suatu kegiatan perdagangan.

Lau dan Lee (1999) menambahkan bahwa terciptanya kepuasan terhadap merek tertentu akan memberikan kepercayaan terhadap merek tersebut. Lau dan Lee (1999) juga mengidentifikasi bahwa pemenuhan janji merupakan anteseden bagi kepercayaan dalam hubungan pemasaran industri. Ketika pelanggan puas dengan suatu merek setelah menggunakan merek tersebut, maka pada situasi yang sama kepercayaan pada suatu merek juga akan terpenuhi. Lau dan Lee (1999) juga mengidentifikasi bahwa pemenuhan janji merupakan anteseden bagi kepercayaan dalam hubungan pemasaran industri. Ketika pelanggan puas dengan suatu merek setelah menggunakan merek tersebut, maka pada situasi yang sama kepuasaan pada suatu merek juga akan terpenuhi.

Menurut Lau dan Lee (1999), prediktor kepercayaan pelanggan terhadap merek antara lain karakteristik merek, karakteristik perusahaan, dan karakteristik hubungan pelanggan, yang pada akhirnya akan mengarah pada loyalitas pelanggan pada merek tersebut. Selanjutnya dikatakan juga oleh Lau dan Lee (1999) bahwa kepuasan terhadap merek juga merupakan anteseden lain yang juga mempengaruhi kepercayaan pelanggan pada merek. Dalam hubungan kepercayaan dan merek, entitas yang dipercaya adalah bukan orang, tapi sebuah simbol. Karena itu, loyalitas terhadap merek melibatkan kepercayaan pada merek. Untuk menciptakan loyalitas dalam pasar saat ini, pemasar harus memfokuskan pada pem- bentukan dan pemeliharaan kepercayaan dalam consumer-brand relationship (Lau dan Lee, 1999).

Berdasarkan konsep teori Perilaku Konsumen (Kotler, 2003), konsumen biasanya belajar dari pengalaman masa lalunya, dan perilaku di masa akan datang diprediksi berdasarkan pada perilaku masa lalunya. Pembelajaran (learning) didefinisikan sebagai perubahan dalam perilaku yang terjadi sebagai hasil dari pengalaman masa lalunya (Assael, 1998). Konsumen memperoleh berbagai pengalaman dalam pembelian produk, mengkonsumsi produk, dan merek produk apa yang disukainya. Ketika pengalaman masa lalunya menyenangkan, pada suatu merek tertentu, maka konsumen akan lebih menunjukkan perilaku yang konsisten sepanjang waktu terhadap merek tersebut (Tjahyadi, 2006).

\section{Hubungan kepuasan terhadap pengecer pada kepercayaan terhadap pengecer}

Berdasarkan hasil pengujian hipotesis ke dua menunjukkan kepuasan terhadap pengecer berpengaruh positif pada kepercayaan terhadap pengecer. Temuan ini konsisten dengan penelitian Zboja dan Voorhees (2006) untuk konteks speciality product berupa barang elektronik. Dalam meta-analisis kepuasan dalam marketing, Geyskens et al., (1999) menemukan kepuasan merupakan anteseden dari kepercayaan. Hasil serupa ditemukan dalam setting pengecer (Bloemeer dan OderkerkenSchroe'der, 2002), seperti yang diusulkan dalam jasa oleh Singh dan Sirdeshmukh (2000). Kepercayaan akan terbangun dengan sendirinya ketika konsumen mendapatkan kepuasan. Kepuasan yang terbentuk akan melahirkan kepercayaan pada pengecer sebagai wakil dari perusahaan manufaktur. Kepuasan yang selama ini terbangun lebih disebabkan pada pengalaman berhubungan dengan pengecer.

\section{Hubungan kepuasan terhadap merek pada kepuasan terhadap pengecer}

Berdasarkan hasil pengujian hipotesis ke tiga menunjukkan kepuasan terhadap merek berpengaruh positif pada kepercayaan terhadap pengecer. Temuan ini konsisten dengan penelitian Zboja dan Voorhees (2006) untuk konteks speciality product berupa barang elektronik. Pengalaman-pengalaman positif 
yang dialami konsumen terhadap suatu merek nantinya akan menimbulkan efek emosional dan kepuasan di benak konsumen. Terciptanya kepuasan pada merek awalnya karena kenyataan yang diterima konsumen melebihi harapannya terhadap merek tersebut. Lau dan Lee (1999) menjelaskan lebih lanjut bahwa dengan terciptanya kepuasan pada merek akan memberikan kepuasan juga pada pengecer.

\section{Hubungan kepercayaan terhadap merek pada kepercayaan terhadap pengecer}

Berdasarkan hasil pengujian hipotesis ke empat menunjukkan kepercayaan terhadap merek berpengaruh positif pada kepercayaan terhadap pengecer. Temuan ini konsisten dengan penelitian Zboja dan Voorhees (2006) untuk konteks speciality product berupa barang elektronik. Kepercayaan pelanggan pada merek didefinisikan sebagai keinginan pelanggan untuk bersandar pada sebuah merek dengan risiko-risiko yang dihadapi karena ekspektasi terhadap merek itu akan menyebabkan hasil yang positif (Lau dan Lee, 1999). Lou dan Lee (1999) berpendapat bahwa merek merupakan indikator bagi perusahaan manufaktur dalam menjalankan kontak dengan konsumen. Hal ini terjadi karena konsumen untuk produk tertentu membeli produk melalui perantara (pengecer), sehingga tidak memiliki kontak personal dengan produsen.

Dalam pasar konsumen, ada begitu banyak konsumen yang tidak teridentifikasi, sehingga sulit bagi perusahaan untuk membangun hubungan personal dengan setiap pelanggan (Lau dan Lee, 1999). Cara lain yang ditempuh oleh pemasar untuk membangun hubungan personal dengan pelanggan adalah melalui sebuah simbol, yaitu merek. Dalam situasi tersebut, merek berperan sebagai pengganti hubungan person-to-person antara perusahaan dengan pelanggannya, selanjutnya kepercayaan dapat dibangun melalui merek. Dalam konteks saluran pemasaran, ketika perusahaan dinilai memiliki reputasi yang baik, maka pelanggan kemungkinan besar akan percaya pada pengecer dan vendor (Anderson dan Weitz, 1992).

Boulding (1956) mengkaitkan bahwa perilaku manusia lebih dikendalikan oleh persepsi image dibandingkan realita obyektif. Persepsi, sesungguhnya kadang merupakan realita dalam pikiran konsumen. Jika pengecer dapat menciptakan koneksi (dalam pikiran konsumen) dengan merek populer yang dibawa, pengecer dapat memperoleh manfaat dari powerfull brand. Merek yang baik dan kuat dibenak konsumen akan melahirkan manfaat bagi konsumen sehingga pada akhirnya dapat melahirkan kepercayaan juga pada merek itu sendiri. Adanya kepercayaan pada merek ini akan memunculkan kepecayaan kepada pengecer, karena pengecer dianggap jalannya konsumen mendapatkan merek. Sehingga semakin meningkat kepercayaan konsumen pada merek yang digunakannya maka akan meningkatkan kepercaanya pada pengecer.

\section{Hubungan kepuasan terhadap pengecer pada niat membeli ulang}

Berdasarkan hasil pengujian hipotesis ke lima menunjukkan kepuasan terhadap pengecer berpengaruh positif pada niat membeli ulang, Temuan ini konsisten dengan penelitian Zboja dan Voorhees (2006) untuk konteks speciality product berupa barang elektronik. Kepuasan pelanggan dapat dikonseptualisasikan sebagai keseluruhan evaluasi pelanggan atas performance dari suatu penawaran (Gustafsson et al., 2005). Kepuasan pelanggan telah diakui sebagai determinan penting loyalitas pelanggan (Bearden dan Teel, 1983).

Niat membeli ulang, sama dengan kesetiaan, keinginan untuk membayar price premium, word-of-mouth, dan tuntutan yang merepresentasikan lima niat keperilakukan yang digambarkan oleh Zeithaml et al., (1996). Kesetiaan dan aspek pembelian kembali dari taksonomi yang pada dasarnya bersifat serupa. Oliver et al., (1997) sebagai contoh tindakan operasional kesetiaan berupa pengulangan penggunaan. Delgado-Ballester dan MunueraAlema'n (2001) dan Macintosh dan Lockshin (1997) menggunakan niat membeli kembali sebagai elemen kesetiaan dalam konteks merek dan toko. Terdapat beberapa perdebatan dalam literatur berkaitan dengan dampak kepuasan pada niat membeli kembali dan kepuasan. Delgado-Ballester et al., (2003) menyarankan bahwa kepuasan mempengaruhi kesetiaan secara langsung.

Salah satu faktor penentu kesuksesan dalam menciptakan niat membeli ulang para 
pelanggan adalah menciptakan kepuasan. Konsumen akan membeli ulang terhadap suatu merek bila mendapatkan kepuasan dari merek tersebut. Begitu juga konsumen akan membeli ulang pada suatu pengecer apabila mendapatkan kepuasan dari pengecer tersebut. Hipotesis berikut mengusulkan hubungan langsung dari kepuasan pada pengecer dengan niat membeli ulang.

\section{Hubungan kepercayaan terhadap pengecer pada niat membeli ulang}

Berdasarkan hasil pengujian hipotesis ke enam menunjukkan kepercayaan terhadap pengecer berpengaruh positif pada niat membeli ulang. Temuan ini konsisten dengan penelitian Zboja dan Voorhees (2006) untuk konteks speciality product berupa barang elektronik. Morgan dan Hunt (1994) mengkonseptualisasikan kepercayaan ketika satu kelompok memiliki keyakinan bahwa partner pertukaran memiliki reliabilitas dan integritas. Kepercayaan sebagai suatu keadaan yang melibatkan ekspektasi positif mengenai motif-motif dari pihak lain yang berhubungan dengan diri seseorang dalam situasi yang berisiko (Lau dan Lee, 1999). Kepercayaan cukup penting dalam relational exchange. Kepercayaan merupakan batu penjurunya hubungan partnership strategis karena karakteristik hubungan melalui kepercayaan sangat bernilai yang mana suatu kelompok berkeinginan untuk menjalankan komitmen terhadap dirinya atas hubungan tersebut (Morgan dan Hunt, 1994). Lau dan Lee (1999) menambahkan bahwa kepercayaan merupakan harapan dari pihak-pihak dalam sebuah transaksi, dan risiko yang terkait dengan perkiraan dan perilaku terhadap harapan tersebut.

Kepercayaan memiliki peran yang penting dalam pemasaran industri. Dinamika lingkungan bisnis yang cepat memaksa pemasaran perusahaan untuk mencari cara yang lebih kreatif dan fleksibel untuk beradaptasi. Untuk tetap bertahan dalam situasi tersebut, perusahaan akan mencari cara yang kreatif melalui pembentukan hubungan yang kolaboratif dengan pelanggan (Lau dan Lee, 1999). Kepercayaan dianggap sebagai cara yang paling penting dalam membangun dan memelihara hubungan dengan pelanggan dalam jangka panjang. Kepercayaan, dalam pemasaran industri, dikonseptualisasikan sebagai feature of relationship quality (Dwyer, Schurr, dan Oh, 1987), dan sebagai determinant of relationship quality (Anderson dan Weitz, 1992).

Kepercayaan memiliki dua dimensi, yaitu kredibilitas dan benevolence. Kredibilitas didasarkan pada keyakinan akan keahlian partner untuk melakukan tugasnya secara efektif dan dapat diandalkan. Benevolence adalah suatu keyakinan bahwa maksud dan motivasi partner akan memberikan keuntungan bersama (Doney dan Canon, 1997). Hal ini menjelaskan bahwa penciptaan awal hubungan dengan partner didasarkan pada kepercayaan.

Kepercayaan pada pengecer dalam beberapa literatur menjadi perdebatan tentang pengaruhnya pada niat membeli ulang. Banyak yang menemukan hubungan langsung (misalnya Bearden dan Teel, 1983; Cronin dan Taylor, 1992; Oliver et al., 1997; Selnes, 1998), sedangkan yang lain menyarankan bahwa kepercayaan adalah anteseden yang dominan dari niat membeli ulang (misalnya Doney dan Cannon, 1997). Perdebatan belum selesai karena Ranaweera dan Prabhu (2003) menemukan kepercayaan dan kepuasan memiliki dampak positif pada ingatan konsumen. Garbarino dan Johnson (1999) menemukan kepuasan menjadi kunci untuk ocasional consumer, sedangkan kepercayaan lebih penting untuk pelanggan yang konsisten. Delgado-Ballester et al., (2003) juga menyarankan bahwa kepercayaan mempengaruhi kesetiaan secara langsung.

Kepercayaan pada pengecer dapat dibangun melalui hubungan yang baik antara konsumen dengan pengecer. Hubungan yang baik ini juga tidak lepas dari kepuasan yang diterima oleh konsumen dari apa yang telah ditawarkan oleh pengecer. Ketika konsumen mendapatkan kepuasan dari pelayanan yang telah diberikan akan menimbulkan kepercayaan dari konsumen terhadap pengecer tersebut. Dalam jangka waktu tertentu apabila hubungan ini terjalin dengan baik maka akan tercipta keinginan untuk terus menjalin hubungan dengan pengecer tersebut. Sehingga dapat dikatakan bahwa terciptanya kepercayaan pada pengecer akan memunculkan niat membeli ulang. Hipotesis berikut mengusulkan hubungan langsung dari kepercayaan pada pengecer dengan niat membeli ulang. 
Hubungan kepercayaan terhadap merek pada niat membeli ulang dimediasi oleh kepercayaan pada pengecer

Berdasarkan hasil pengujian hipotesis ke tujuh menunjukkan kepercayaan terhadap merek pada niat membeli ulang dimediasi oleh kepercayaan terhadap pengecer. Temuan ini konsisten dengan penelitian Zboja dan Voorhees (2006) untuk konteks speciality product berupa barang elektronik. Dalam perspektif relasional, kepercayaan merupakan variabel yang memediasi hubungan antara sikap tertentu dan behavioral outcomes (Morgan dan Hunt, 1994). Kepercayaan pada merek (brand trust) menggambarkan suatu komponen yang penting dari penempatan internal atau sikap yang diasosiasikan dengan loyalita merek (Lau dan Lee, 1999).

Kepercayaan pelanggan pada merek memberikan kontribusi pada intensi pelanggan untuk membeli kembali merek yang sama di masa akan datang, dan intensi mereka untuk merekomendasikan merek tersebut pada orang lain. Oleh karena itu, pemasar perlu membangun kepercayaan pelanggan pada merek yang mereka tawarkan. Untuk membangun kepercayaan pada merek, pemasar perlu memahami dan mengembangkan karakteristikkarakteristik yang mempengaruhi kepercayaan pelanggan pada merek, yaitu karakteristik merek, karakteristik perusahaan dan karakteristik hubungan pelanggan-merek.

Pengecer mendapatkan sejumlah manfaat dari mendapatkan powerfull brand, termasuk peningkatan image untuk pengecer dengan konsumen, hubungan kepercayaan dan kredibilitas dengan konsumen, dan pre-established demand (Webster, 2000). Dua manfaat pertama yang diperoleh yaitu efektif dalam sifat dan ketepatan transfer potensial atas kepuasan merek dan kepercayaan pada pengecer. Dengan kata lain, pre-established demand merupakan sifat alamiah, berimplikasi bahwa peningkatan pertukaran di toko/bisnis yang dihasilkan. Meskipun demikian, pendapat dalam proposal ini adalah permintaan ini diciptakan untuk tujuan tertentu, dan tidak seharusnya untuk situasi pembelian ulang. Oleh karena itu, pre-established demand bisa mendapatkan konsumen dalam toko, tetapi tidak cukup untuk mempertahankan konsumen kembali lagi.

\section{Hubungan kepuasan terhadap merek pada niat membeli ulang dimediasi oleh kepuasan pada pengecer}

Berdasarkan hasil pengujian hipotesis ke delapan menunjukkan kepuasan terhadap merek pada niat membeli ulang dimediasi oleh kepuasan terhadap pengecer. Temuan ini konsisten dengan penelitian Zboja dan Voorhees (2006) untuk konteks speciality product berupa barang elektronik. Kepuasan pelanggan dapat dikonseptualisasikan sebagai keseluruhan evaluasi pelanggan atas performance dari suatu penawaran (John dan Fornell, 1991, dalam Gustafsson, Johnson, dan Roos, 2005). Kepuasan konsumen adalah penilaian evaluatif atas pilihan terakhir dari transaksi tertentu (Kotler, 2000). Kepuasan dapat dinilai secara langsung sebagai perasaan konsumen secara keseluruhan. Kepuasan konsumen juga dipengaruhi oleh dua faktor yaitu pengharapan dan kinerja jasa yang dialami. Kepuasan terjadi ketika kinerja yang dialami sama atau lebih besar dari pengharapan (Zeithaml, et al, 2009).

Apabila terjadi niat membeli ulang dikemudian hari semua ini tidak lepas karena adanya kepuasan yang terbentuk karena kepuasan pada merek dan kepuasan pada pengecer. Niat membeli ulang dapat muncul karena adanya kepuasan pada pengecer dan karena terciptanya kepuasan pada merek yang terbentuk sebelumnya. Sehingga dapat dijelaskan pula bahwa pengaruh kepuasan pada merek terhadap niat membeli ulang dimediasi oleh kepuasan pada pengecer.

\section{PENUTUP}

Semua hipotesis dinyatakan signifikan. Hipotesis tersebut terdiri dari hubungan langsung dan mediasi. Untuk hipotesis dengan hubungan langsung antara lain: kepuasan terhadap merek pada kepercayaan terhadap merek, kepuasan terhadap pengecer pada kepercayaan terhadap pengecer, kepuasan terhadap merek pada kepuasan terhadap pengecer, kepercayan terahdap merek pada kepercayaan terhadap pengecer, kepuasan terhadap pengecer pada niat membeli ulang, serta hubungan antara kepercayaan terhadap pengecer pada niat membeli ulang.

Untuk hubungan mediasi yaitu ditemukannya signifikansi antara pengaruh kepercayaan terhadap merek pada niat membeli 
ulang dengan dimediasi oleh kepercayaan terhadap pengecer serta pengaruh kepercayaan terhadap merek pada niat membeli ulang dengan dimediasi oleh kepuasan terhadap pengecer. Hal ini menyimpulkan bahwa model penelitian sebelumnya (Zboja dan Verhoor, 2006) dengan menggunakan obyek speciality good dapat berlaku juga untuk barang convenience.

\section{Keterbatasan Penelitian dan Penelitian yang Akan Datang}

Uji model penelitian tidak mempertimbangkan perbedaan merek shampo dan jenis pengecer tempat pembelian oleh konsumen. Hal ini dilakukan karena banyaknya variasi jenis shampo dan tempat pembelian. Sehingga hal ini dapat mengurangi kemampuan eksternal validitas hasil penelitian.

Penelitian ini mengunakan kuesioner yang bersifat self report. Sehingga masih dimungkinkan muncul bias dengan rendahnya validitas internal.

Saran untuk penelitian yang akan datang yaitu untuk melakukan penelitian dengan dua jenis barang yaitu barang high involvement dan barang low involvement. Alat analisa penelitian perlu ditambah meliputi uji beda serta pengujian kualitas model dengan alat analisa SEM. Sehingga akan bisa dibandingkan penggunaan model untuk barang high involvement dan barang low invovement.

\section{DAFTAR PUSTAKA}

Anderson, Erin, and Barton, Weitz. 1992. The Use of Pledges to Build and Sustain Commitment in Distribution Channels. Journal of Marketing Research, 29 (February). 18-34.

Anderson, J.C., and Narus, A. 1990. A Model of Distribution Firm and Manufacturing Firm Working Parthnership. Journal of Marketing, Vol. 54, January. 42-58.

Andreassen, T.W. 1994. Satisfaction, Loyalty and Reputation as Indicators of Customer Orientation in the Public Sector. International Journal of Public Sector Management, Vol. 7, No.2.1634.
Assael, H. 1998. Consumer Behavior and Marketing Action. $6^{\text {th }}$ ed. Cincinatti, OH: South Western College Publishing.

Baron, R.M. and Kenny, D.A. 1986. The Moderator-mediator Variable Distinction in Social Psychological Research: Conceptual, Strategic, and Statistical Considerations. Journal of Personality and Social Psychology. Vol. 51 No. 6. 1173-82.

Barnes, James, G. 2003. Establishing Meaningful Customer Relationships: Why some companies and brands mean more to their customers. Managing Service Quality. Vol.13 No. 3. 178186.

Bearden, W. O. and Teel, J. E. 1983. Selected Determinants of Customer Satisfaction and Complaint Reports. Journal of Marketing Research. 20 (February). 21-28.

Beatty, S.E; Mayer, M.L; Coleman, J.E.; Reynolds, K.E; and Lee, J. 1996. Customer-sales associate retail relationships. Journal of Retailing. Vol. 72. $223-47$.

Berry, L.L. 2000. Cultivating Service Brand Equity. Journal of the Academy of Marketing Science. Vol. 28 No. 1. 12837.

Bloemeer, J. and Odekerken-Schro"der, G. 2002. Store satisfaction and store loyalty explained by customer- and store-related factors. Journal of Customer Satisfaction, Dissatisfaction and Complaining Behavior. Vol. 15. 68-80.

Bloemer, J.M. and Kasper, H. 1995. The complex relationship between consumer satisfaction and brand loyalty. Journal of Economic Psychology. Vol. 16. 1129.

Boulding, K.E. 1956. The Image, The University of Michigan Press, Ann Arbor, MI.

Boon, S.D., and Holmes, J.G. 1991. The dynamics of interpersonal trust: Resolving uncertainty in face of risk. In 
Cooperation and prosaically behavior, R.A. Hinde \& J. Groebel (Eds.), Cambridge, UK: Cambridge University Press. 190-211.

Chan, Syafruddin. 2003. Relationship Marketing: Inovasi Pemasaran yang Membuat Pelanggan Bertekuk Lutut, Jakarta: Gramedia.

Cobb-Walgren, Cathy, Cynthia A.R., and Naveen, D. 1995. Brand Equity, Brand Preference and Purchase Intent. Journal of Advertising. 24 (3). 25-40.

Cooper, D.R. and Schindler P.S., 2008. Business Research Methods. 10th ed. New York, NY: McGraw-Hill/Irwin.

Cronin, J.J. and Taylor, S.A. 1992. Measuring service quality: a reexamination and extension. Journal of Marketing. Vol. 56 No. 3. 55-68.

Delgado-Ballester, E. and Munuera-Alema'n, J.L. 2001. Brand trust in the context of customer loyalty. European Journal of Marketing. Vol. 35 No. 11. 1238-58.

Delgado-Ballester, E., Munuera-Alema'n, J.L. and Yagu" e-Guille'n, M.J. 2003. Development and validation of a brand trust scale. International Journal of Market Research. Vol. 45 No. 1. 35-53.

Dodds, W.B., Monroe, K.B. and Grewal, D. 1991. The effects of price, brand, and store information on buyers' product evaluations. Journal of Marketing Research. Vol. 28. 307-19.

Doney, P.M. and Cannon, J.P. 1997. An examination of the nature of trust in buyer-seller relationship. Journal of Marketing. Vol. 61. 35-51.

Donney, Patricia M. and Joseph P. Cannon. 1997. An Examination of The Nature of Trust in Buyer-Seller Relationships. Journal of Marketing. Vol. 61. No. 2. 35-51.

Dwyer, F. Robert, Paul H. Schurr, and Sejo Oh. 1987. Developing Buyers-Seller Relationships. Journal of Marketing. Vol.51 (April). 11-27.
Evan, Joel R. and Laskin, R. L. 1994. The Relationship Marketing Proses: A Conceptualization and Aplication. Industrial Marketing Management. Vol. 23. 439-452.

Farris, P.W. and Ailawadi, K. 1992. Retail power: monster or mouse? Journal of Retailing. Vol. 68. 351-69.

Fornell, C. 1987. A second generation of multivariate analysis: Classification of methods and implications for marketing research in Review of Marketing, Houston, M.J. (Ed.). American Marketing Association, Chicago. 407-450.

Fornell, C., Michael, D. Johnson., Eugene, W. Anderson., Jaesung, C. and Barbara, E. B. 1996. The American Customer Satisfaction Index: Nature, Purpose and Findings. Journal of Marketing. Vol. 60. 7-17.

Ganesan, S. 1994. Determinants of Long-Term Orientation in Buyer-Seller Relationship. Journal of Marketing. Vol. 58. 119.

Garbarino, E. and Johnson, M. S. 1999. The Different Roles of Satisfaction, Trust and Commitment in Customer Relationships. Journal of Marketing. Vol. 63. 70-87.

Geyskens, I.J-B; Steenkamp, E.M; and Kumar, N. 1999. A meta-analysis of satisfaction in marketing channel relationships. Journal of Marketing Research. Vol. 36. 223-38.

Goff, B.G; Boles, J.S; Bellenger, D.N; and Stojack, C. 1997. The influence of salesperson selling behaviors on customer satisfaction with products. Journal of Retailing. Vol. 73. 171-84.

Gustafsson, A., Johnson, M. D. and Roos, I. 2005. The Effects of Customer Satisfaction, Relationship Commitment Dimensions, and Triggers on Customer Retention. Journal of Marketing. 69 (October). 210-218.

Hair, JosephF., JR; Rolph E. Anderson; Ronald L. Tatham and William. C. Black. 
2006. Multivariate Analisys. 5th edition. Prentice Hall International. Inc.

Krishnan, B.C. and Hartline, M.D. 2001. Brand equity: is it more important in services? Journal of Services Marketing. Vol. 15 Nos 4/5. 328-31.

Kuntjara. 2007. Analisis Faktor-faktor yang Mempengaruhi Minat Beli Ulang Konsumen (Studi kasus di PT Wijaya Karya Beton Wilayah IV; Jateng, DIY, Kalsel dan Kalteng), Tesis Program Studi Magister Manajemen Program Pasca Sarjana Universitas Diponegoro Semarang, (Tidak Dipublikasikan).

Lau, T. Geok and Lee, H.S. 1999. Consumer Trust in a Brand and The Link to Brand. Journal of Marketing Focused Management. Vol. 4. 341-70.

Macintosh, G. and Lockshin, L.S. 1997. Retail relationships and store loyalty: a multilevel perspective. International Journal of Research in Marketing. Vol. 5. 48797.

Moorman, C., Zaltman, G. and Rohit, D. 1992. Relationship Between Providers and Users of Market Research: The Dynamics of Trust Within and Between Organizations. Journal of Marketing Research. Vol. 29 (August). 314-328.

Moorman, C; Deshpande, R. and Zaltman, G. 1993. Factors affecting trust in market research relationships. Journal of Marketing. Vol. 57. 81-101.

Morgan, R.M. and Hunt, S.D. 1994. The Commitment-Trust Theory of Relationship Marketing. Journal of Marketing. Vol. 58. 20-38.

Oliver, R. L. 1993. A Conceptual Model of Service Quality and Service Satisfaction : Compatible Goal, Different Concept. In Advance in Service Marketing and Management. Vol. 2. 65-68.

Oliver, R. L. 1999. Whence Consumer Loyalty. Journal of Marketing. Vol. 63. No. 4. 33-44.
Oliver, R.L. and W.S. DeSarbo. 1988. Response Determinants in Satisfaction Judgments. Journal of Customer Research. Vol. 14. 495-507.

Oliver, R.L; Rust, R.T. and Varki, S. 1997. Customer Delight: foundations, findings and managerial insight. Journal of Retailing. Vol. 73 No. 3. 311-36.

Peppers, D. and Martha, Rogers. 2004. Managing Customer Relationships: A Strategic Framework. Canada, New Jersey: John Wiley \& Sons, Inc.

Puspitasari, Dian. 2006. Analisis Pengaruh Persepsi Kualitas dan Kepuasan Pelanggan terhadap Minat Beli Ulang (Studi Kasus pada Maskapai Penerbangan Garuda Keberangkatan Semarang). Tesis Program Studi Magister Manajemen Program Pasca Sarjana Universitas Diponegoro Semarang, (Tidak Dipublikasikan).

Rajaobelina, L. and Bergeron, J. 2009. Antecedents and Consequences of Buyer-Seller Relationship Quality in the Financial Service Industry," International Journal of Bank Marketing, Vol. 27, No. 5, pp. 359380.

Ranaweera, C. and Prabhu, J. 2003. The influence of satisfaction, trust and switching barriers on customer retention in a continuous purchasing setting. International Journal of Service Industry Management. Vol. 14 No. 4. 374-95.

Sambandam, Rajan, and Lord Kenneth R. 1995. Switching Behavior In Automobile Markets: A Consideration - Sets Model. Journal of The Academy of Marketing Science. Vol. 23, No. 1.

Selnes, F. 1993. An Examination of the Effect of Product Performance on Brand Reputation, Satisfaction and Loyalty. Journal of Marketing. Vol. 27 No. 9. 19-35.

Selnes, F. (1998), "Antecedents and consequences of trust and satisfaction in buyer-seller relationships," European 
Journal of Marketing, Vol. 32 No. 3, pp. 305-22.

Singh, J. (1991), "Understanding the structure of consumers' satisfaction evaluations of service delivery," Journal of the Academy of Marketing Science, Vol. 19, pp. 223-44.

Singh, J. and Sirdeshmukh, D. 2000. Agency and trust mechanisms in customer satisfaction and loyalty judgments. Journal of the Academy of Marketing Science Vol. 28 No. 1. 150-67.

Spreng, A. Richard; Scott B., Mackenzie, and Richard W. Olshavsky. 1996. Reexamination of the Determinants of Customer Satisfaction. Journal of Marketing. Vol. 60, July. 15-32.

Tse D.K. and Wilton P.C. 1998. Models of Consumer Satisfaction Formation: An Extension. Journal of Marketing Research. Vol. XXV, May, 1988. 204212

Webster, F.E. 2000. Understanding the relationships among brands, consumers, and resellers. Journal of the Academy of Marketing Science. Vol. 28 No. 1. 17-23.

Widarjono, Agus 2010. Analisis Statistika Multivariat Terapan. Yogyakarta: UPP STIM YKPN.

Woodside, Arch, G; Lisa, L. F. \& Robert, Timothy, Daly. 1989. Linking Service Quality, Customer Satisfaction, and Behavior Intention. Journal of Health Care Marketing. Vol. 9, No.2. 30-48.

Zboja, J. James and Voorhees, M. Clay. 2006. The impact of brand trust and satisfaction on retailer repurchase intentions. Journal of Services Marketing. Vol.20 No.5. 381-390.

Zeithaml, V. A., Berry, L. L. and Parasuraman, A. 1996. The Behavioral Consequences of Service Quality. Journal of Marketing. Vol. 60. 31-46.

Zeithaml V., Bitner M. J., and Gremler, D. D. 2009. Service Marketing: Interating Customer Focus Across the Firm. McGraw Hill International Edition. 